\title{
Hubungan Dukungan Keluarga Terhadap Manajemen Laktasi Pada Ibu Bekerja
}

\author{
Arlia Purwaningsih $^{\mathrm{a}}$, Oswati Hasanah ${ }^{\mathrm{a}}$, Wasisto Utomo ${ }^{\mathrm{a}}$ \\ "Universitas Riau \\ E-mail: arlia.purwaningsih@yahoo.com
}

\begin{abstract}
The purpose of this research was to determine the relationship between family support and lactation management among working mothers. This research was a descriptive correlation with cross sectional approach, conducted among 35 working mothers who work as a nurse in Arifin Achmad Hospital in Pekanbaru taken with total sampling. A set of valid and reliable questionnaire used to collect the data. The results showed a weak positive correlation in different direction between family support and lactation management $(r=0.295)$, with $P$ value $=0,086(>0,05)$, this resulst indicates that there was no significant correlation between two variable. This result suggest a nurse as a working mother to improve their social environment while breastfeeding to motivate, persuade, and support them on performing optimal lactation management.
\end{abstract}

Key words: family support, lactation management, working mother, nurse

\begin{abstract}
Abstrak: Tujuan dari penelitian ini adalah untuk menentukan hubungan antara dukungan keluarga dengan manajemen laktasi pada ibu bekerja. Penelitian ini adalah korelasi deskriptif dengan pendekatan crossectional, dilakukan pada 35 wanita pekerja yang bekerja sebagai perawat di rumah sakit ahmad arifin di pekanbaru dengan cara total sampling. Kumpulan kuesioner yang valid dan reliable di gunakan untuk mengumpulkan data. Hasil menunjukkan korelasi positif yang lemah dalam petunjuk berbeda antara dukungan keluarga dan manajemen laktasi $(r=0,295)$, dengan $\mathrm{P}$ value $=0,086(>0,05)$, hasil menunjukkan tidak adanya korelasi signifikan antara dua variable. Hasil menyarankan perawat yang sebagai orang tua pekerja untuk meningkatkan lingkungan sosialnya ketika menyusui untuk memotivasi, meyakinkan dan mendukung mereka dalam melakukan manajemen laktasi yang optimal
\end{abstract}

Kata kunci : dukungan keluarga, manajemen laktasi, ibu pekerja, perawat

\section{PENDAHULUAN}

World Health Organization (WHO) dan United Nations of Children's Fund (UNICEF) dalam Global Strategy on Infant and Young Child Feeding (2002) merekomendasikan pola pemberian makanan terbaik bagi bayi sejak lahir sampai usia 6 bulan, kemudian setelahnya ditambah dengan pemberian MP-ASI (Makanan Pendamping ASI) tepat setelah bayi berusia 6 (enam) bulan, kemudian pemberian ASI tetap dilanjutkan hingga anak berumur 2 (dua) tahun (Depkes RI, 2007).

Pemberian ASI yang dimulai secara eksklusif memberi keuntungan bagi keluarga dan negara karena dapat meningkatkan jalinan ikatan antara ibu dan bayi, mengurangi angka kesakitan, pemberiannya lebih praktis serta ekonomis karena pengeluaran rumah tangga untuk membeli susu formula dan biaya perawatan anak sakit akan berkurang sehingga negara akan memiliki sumber daya manusia yang berkualitas (Lowdermilk \& Perry, 2004; Datta, 2009).

Depkes RI menargetkan cakupan ASI Eksklusif sebesar 80\%, namun angka ini masih sangat sulit untuk dicapai (Syafiq \& Fikawati, 2010). Hasil Survei Sosial Ekonomi Nasional (Susenas) tahun 2010, cakupan pemberian ASI Eksklusif di Indonesia masih dibawah target yaitu pada bayi usia 0-6 bulan dengan angka cakupan $61,5 \%$. Sedangkan pada bayi usia 6 bulan masih sangat rendah yaitu $33,6 \%$ (Kemenkes RI Direktorat Jenderal Bina Gizi dan Kesehatan Ibu dan Anak, 2012). Di Kota Pekanbaru, pencapaian ASI 
Eksklusif pada bayi usia 6 bulan juga belum optimal yaitu sebesar $47,89 \%$ pada tahun 2010 dan mengalami penurunan menjadi $46,81 \%$ pada tahun 2011 (Dinas Kota Pekanbaru, 2012).

Masalah utama rendahnya pemberian ASI Eksklusif di Indonesia adalah pengaruh faktor sosial budaya, kurangnya pengetahuan ibu hamil, keluarga, dan masyarakat (Riskesdas, 2010), serta tenaga kesehatan yang belum sepenuhnya mendukung peningkatan pemberian ASI (PP-ASI), termasuk institusi yang mempekerjakan perempuan yang belum memberikan tempat dan kesempatan bagi ibu menyusui di tempat bekerja (InfoPublik Dirjen Informasi dan Komunikasi Publik, 2010).

Pada ibu bekerja, penyebab kurangnya cakupan pemberian ASI eksklusif adalah singkatnya masa cuti hamil atau melahirkan yaitu rata-rata hanya tiga bulan, keterbatasan waktu atau kesibukan kerja, dan ketersediaan fasilitas untuk menyusui di tempat kerja menyebabkan penggunaan susu botol atau susu formula diberikan lebih dini (Kementerian Kesehatan, 2012). Semakin banyak wanita yang bekerja, akan mempengaruhi upaya ibu menyusui bayi (Swandari, 2013).

Profesi keperawatan merupakan salah satu profesi dengan persentase tenaga kerja wanita yang cukup besar. Perawat dituntut untuk bisa menjadi role model bagi masyarakat khususnya dalam penerapan manajemen laktasi. Manajemen laktasi adalah upaya yang dilakukan ibu untuk tetap dapat memberikan ASI bagi bayinya pada masa postnatal atau masa menyusui yang ruang lingkupnya meliputi pemberian ASI eksklusif, teknik menyusui, memerah ASI, menyimpan ASI perah, memberikan ASI perah, dan pemenuhan gizi selama periode menyusui (Agoestingoe, 2011). Saat ini masih banyak ibu bekerja termasuk perawat yang belum dapat menjalankan peran ini secara efektif (Harjanti, 2010).
Penelitian Wulandari, Komariah, \& Ermiati (2009) terhadap ibu yang bekerja sebagai perawat di RS Al.Islam Kota Bandung menunjukkan bahwa sebagian besar responden memiliki pengetahuan kategori cukup dan sangat sedikit sikap responden yang favorable terhadap pemberian ASI Eksklusif. Penelitian Harjanti (2010) tentang perilaku perawat dalam manajemen laktasi di RSUD Tugorejo Semarang didapatkan hasil perilaku manajemen laktasi kategori baik pada ibu yang bekerja sebagai perawat hanya teknik menyusui dan asupan nutrisi selama ibu masa menyusui, sedangkan pemberian ASI Eksklusif, cara memerah ASI, cara menyimpan ASI Perah, dan cara memberikan ASI Perah kepada bayi masih berada pada perilaku kategori buruk.

Keberhasilan seorang ibu untuk terus menyusui bayinya juga dipengaruhi oleh dukungan dari keluarga (Rejeki, 2008; Manaf, 2010; Simbolon, 2011). Keluarga dapat memberikan dukungan berupa dukungan informasional, dukungan penilaian/bimbingan, dukungan instrumental, dan dukungan emosional (Friedman, 2003). Dukungan keluarga yang paling berpengaruh terhadap keberhasilan ibu dalam menyusui yaitu dukungan emosional (Manaf, 2010; Simbolon, 2011) dan dukungan informasional (Simbolon, 2011). Pemberian dukungan dari suami dan keluarga dapat meningkatkan kepercayaan diri, kenyamanan, dan pengalaman keberhasilan ibu dalam menyusui (Lowdermilk \& Perry, 2004; Basavanthappa, 2006).

Studi pendahuluan bulan Oktober dan November 2012 dilakukan dengan observasi pada salah satu tempat kerja dan wawancara pada tiga orang perawat. Berdasarkan hasil observasi yang peneliti lakukan, di Rumah Sakit Umum Daerah Arifin Achmad Pekanbaru (RSUD) sudah ada ruang laktasi khusus yaitu terdapat di Gedung Utama dan ruang Perinatologi. Berdasarkan beberapa kali pengamatan 
ruang laktasi yang terdapat di Gedung Utama tidak pernah terlihat ada ibu-ibu yang menyusui bayinya, didalam ruang laktasi tersebut terdapat tempat duduk untuk ibu dan tempat untuk mencuci tangan. Sedangkan ruang laktasi di Perinatologi sering terlihat digunakan oleh ibu yang bayinya dirawat, dan hanya sebagian kecil perawat yang menyusui memanfaatkan fasilitas ini. Hampir semua ruangan di RSUD Arifin Achmad Pekanbaru tersedia lemari pendingin/kulkas yang bisa digunakan oleh perawat untuk menyimpan ASI Perah, namun tidak semua perawat yang sedang masa menyusui memanfaatkan fasilitas ini secara optimal. Sebagian besar kulkas tersebut lebih banyak digunakan untuk penyimpanan obat dan makanan.

Hasil wawancara pada tiga orang perawat, satu orang tinggal bersama suami dan ibu kandung tidak bisa memberikan ASI Eksklusif, karena saat ini bekerja. Bayi dititipkan kepada keluarga dan diberikan susu formula karena dianggap lebih praktis. Sedangkan wawancara dengan dua orang perawat yang bekerja di RSUD Arifin Achmad Pekanbaru yang tinggal bersama suami, salah seorang demikian juga tidak bisa memberikan ASI Eksklusif, sebaliknya seorang perawat lainnya sampai saat ini masih bisa memberikan ASI kepada bayinya. Salah seorang kepala ruangan mengatakan di RSUD Arifin Achmad Pekanbaru sudah ada kebijakan bagi perawat yang mempunyai anak usia 0-6 bulan hanya dinas pada shift pagi saja dan diberikan kesempatan pulang lebih awal satu jam dari jadwal biasanya. Namun, penerapannya tergantung kebijakan masing-masing kepala ruangan. Berdasarkan latar belakang tersebut, peneliti tertarik melakukan penelitian di RSUD Arifin Achmad Pekanbaru tentang adakah hubungan dukungan keluarga terhadap manajemen laktasi pada ibu bekerja (perawat). Tujuan dari penelitian ini adalah untuk mengetahui hubungan antara dukungan keluarga terhadap manajemen laktasi pada ibu bekerja (perawat).

\section{METODE}

Desain Penelitian: Penelitian ini termasuk dalam penelitian kuantitatif dengan desain penelitian yang digunakan yaitu studi korelasi (correlational studies) atau disebut juga deskriptif korelasi (descriptive correlational) dengan pendekatan yang digunakan yaitu cross sectional.

Sampel: Sampel yang digunakan sebanyak 35 orang responden (perawat) di RSUD Arifin Achmad Pekanbaru menggunakan teknik total sampling dengan kriteria inklusi yang digunakan yaitu bersedia menjadi responden, perawat yang pernah menyusui bayinya saat kembali bekerja, mempunyai anak usia 1 - 24 bulan, tidak sedang dalam masa cuti, tidak menderita penyakit yang menyebabkan ibu tidak dianjurkan menyusui, dan tinggal dengan anggota keluarga lain (suami/ orangtua/ mertua/ saudara).

Instrumen: Instrumen yang digunakan berupa kuesioner tentang data demografi responden, variabel manajemen laktasi yang terdiri dari 13 pernyataan positif dan negatif dengan skala likert, dan variabel dukungan keluarga yang terdiri dari 22 pertanyaan dengan menggunakan skala guttman yang sebelumnya telah dilakukan uji validitas dan reliabilitas.

Prosedur: Tahapan awal peneliti mengajukan surat permohonan izin penelitian ke PSIK UR dan RSUD Arifin Achmad Pekanbaru, kemudian kuesioner diberikan kepada responden dengan bantuan kepala ruangan agar peneliti dapat berkenalan dengan responden dan menyampaikan tujuan serta cara pengisian kuesioner, kemudian responden diberikan waktu 15-20 menit untuk mengisi jawaban, sedangkan bagi sebagian responden yang sangat sibuk diberikan waktu untuk membawa pulang kuesioner dan keesokan harinya kuesioner tersebut telah diisi 
kemudian dikembalikan kepada peneliti dan peneliti mengucapkan terima kasih.

\section{HASIL DAN PEMBAHASAN Analisa Univariat}

Tabel 1.

Karakteristik data demografi responden

\begin{tabular}{lll}
\hline \multicolumn{1}{c}{ Kategori responden } & Jumlah & $(\%)$ \\
\hline Umur (tahun) & & \\
$-21-35$ tahun (dewasa awal) & 33 & 94.3 \\
$-36-60$ tahun (dewasa tengah) & 2 & 5.7
\end{tabular}

Pendidikan

- Diploma

82.9

- S1 Keperawatan

$29 \quad 82.9$

Status kepegawaian

- PNS

$6 \quad 17.1$

- Honorer

18

51.4

- Lainnya

14

40.0

8.6

\begin{tabular}{lll}
\hline Jumlah anak yang dimiliki & & \\
$-<2$ orang & 12 & 34 \\
-2 - 3 orang & 22 & 63 \\
$->3$ orang & 1 & 3
\end{tabular}

Umur anak terakhir

- < 6 bulan

$\begin{array}{ll}12 & 34 \\ 14 & 40 \\ 9 & 26\end{array}$

Berdasarkan tabel 1 diketahui bahwa sebagian besar responden berada dalam rentang umur 21-35 tahun (dewasa awal) sebanyak $94.3 \%$ dengan pendidikan terakhir terbanyak Diploma III (82.9\%). Mayoritas responden adalah Pegawai Negeri Sipil (PNS) (51.4\%), mayoritas jumlah anak yang dimiliki 2-3 orang $(62.9 \%)$, dan anak terakhir mayoritas berumur $7-12$ bulan (40\%).

Diagram 1.

Distribusi responden berdasarkan ruangan tempat bekerja

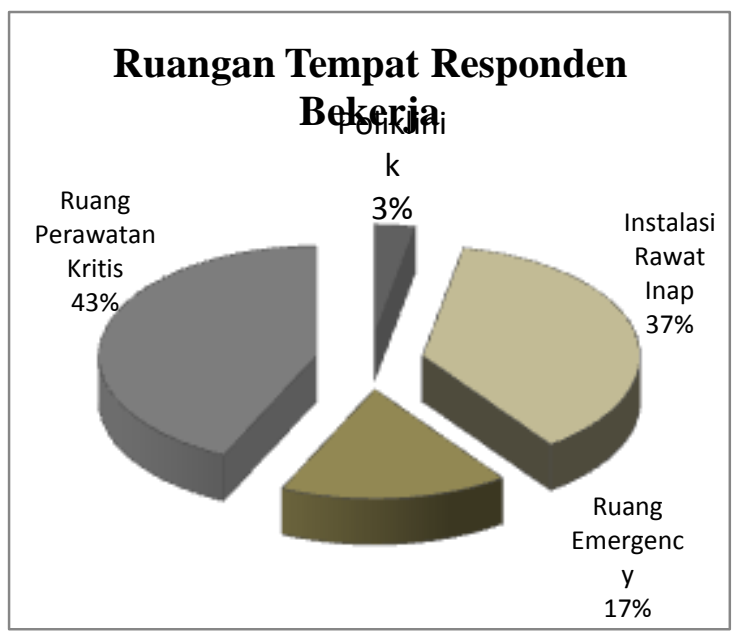

Berdasarkan diagram 1 diketahui bahwa mayoritas perawat yang menjadi responden bekerja di ruang perawatan kritis $(43 \%)$.

Tabel 2.

Frekuensi lama pemberian ASI eksklusif

\begin{tabular}{lcccc}
\hline Variabel & $\begin{array}{c}\text { Mean } \\
\text { (bulan) }\end{array}$ & SD & Min - Max & 95\% CI \\
\hline Lama & 2.49 & 1.597 & $0-6$ & 1.94 \\
pemberian & & & & - \\
ASI & & & & 3.03 \\
Eksklusif & & & & \\
\hline
\end{tabular}

Hasil analisis didapatkan rata-rata lama pemberian ASI eksklusif adalah 2.49 bulan (95 \% CI: 1.94-3.03) dengan standar deviasi 1.597. Dari hasil estimasi interval dapat disimpulkan bahwa $95 \%$ diyakini bahwa rata-rata lama pemberian ASI eksklusif adalah diantara 1.94 bulan sampai dengan 3.03 bulan.

Tabel 3.

Distribusi skor manajemen laktasi

\begin{tabular}{lccccc}
\hline Variabel & Mean & Median & SD & $\begin{array}{c}\text { Min } \\
- \\
\text { Max }\end{array}$ & $\begin{array}{l}\text { 95\% } \\
\text { CI }\end{array}$ \\
\hline $\begin{array}{lcccc}\text { Manajeme } \\
\text { n laktasi }\end{array}$ & 33.43 & 33.00 & 8.566 & 19 & 30.49 \\
& & & & - & - \\
& & & & 49 & 36.37 \\
\hline
\end{tabular}

Hasil analisis didapatkan rata-rata skor manajemen laktasi adalah 33.43 
dengan skor nilai tengah 33.00 (95\% CI: 30.49 - 36.37). Standar deviasi yang dihasilkan besar yaitu 8.566. Skor manajemen laktasi yang didapatkan responden paling rendah 19 dan paling tinggi yaitu 49. Dari hasil estimasi interval dapat disimpulkan bahwa 95\% diyakini bahwa rata-rata skor manajemen laktasi adalah diantara 30.49 sampai dengan 36.37. Hasil ini menunjukkan rata-rata skor manajemen laktasi terletak pada skor pertengahan, artinya skor yang didapatkan responden tidak tinggi dan tidak rendah yang mendekati nilai median.

Tabel 4.

Distribusi skor dukungan keluarga terhadap ibu bekerja

\begin{tabular}{lccccc}
\hline Variabel & Mean & Median & SD & $\begin{array}{c}\text { Min } \\
- \\
\text { Max }\end{array}$ & $\begin{array}{l}95 \% \\
\text { CI }\end{array}$ \\
& & & & \multicolumn{3}{c}{} \\
\hline Dukungan & 15.26 & 16.00 & 4.441 & 8 & 13.73 \\
Keluarga & & & & - & - \\
& & & & 22 & 16.78 \\
\hline
\end{tabular}

Hasil analisis didapatkan rata-rata skor dukungan keluarga terhadap ibu bekerja (responden) adalah 15.26 dengan skor nilai tengah 16.00 (95 \% CI: 13.73 16.78). Standar deviasi yang dihasilkan besar yaitu 4.441. Skor dukungan keluarga terhadap ibu bekerja (responden) paling rendah 8 dan paling tinggi yaitu 22. Dari hasil estimasi interval dapat disimpulkan bahwa 95\% diyakini bahwa rata-rata skor dukungan keluarga adalah diantara 13.73 sampai dengan 16.78. Hasil ini menunjukkan rata-rata skor dukungan keluarga terletak pada skor pertengahan dimana skor ini mendekati nilai median.

\section{Analisa Bivariat}

Tabel 5.

Hubungan dukungan keluarga terhadap manajemen laktasi pada ibu bekerja di RSUD Arifin Achmad Pekanbaru $(n=35)$

\begin{tabular}{llc}
\hline & & $\begin{array}{c}\text { Skor manajemen } \\
\text { laktasi }\end{array}$ \\
\hline Skor dukungan & $\mathrm{r}$ & 0.295 \\
keluarga & $\mathrm{p}$ & 0.086 \\
& $\mathrm{n}$ & 35 \\
\hline
\end{tabular}

Berdasarkan uji korelasi Pearson antara variabel skor manajemen laktasi dan skor dukungan keluarga pada ibu bekerja menunjukkan korelasi (r) sebesar 0.295. Angka tersebut bermakna adanya korelasi positif yang lemah $(0.20-0.399)$ dan searah. Artinya, semakin besar variabel skor dukungan keluarga maka variabel skor manajemen laktasi pada ibu bekerja juga semakin besar. Dari hasil analisa tersebut diperoleh juga $\mathrm{P}$ value sebesar 0.086 ( $\mathrm{P}$ value $>0,05)$ yang menunjukkan bahwa antara keduanya tidak terdapat korelasi yang bermakna, ini berarti $\mathrm{H}_{0}$ gagal ditolak, sehingga tidak ada hubungan antara dukungan keluarga terhadap manajemen laktasi pada ibu bekerja.

\section{A. Karakteristik responden}

1. Karakteristik demografi responden

Penelitian yang telah dilakukan terhadap 35 orang responden didapatkan hasil bahwa mayoritas responden berada pada kelompok umur 21-35 tahun (dewasa awal) $94.3 \%$ (33 orang). Dewasa awal merupakan tahap usia produktif, usia dimana seorang individu termasuk wanita memiliki tugas perkembangan yaitu membangun karier/bekerja, membina hubungan melalui pernikahan, dan bagi wanita merupakan usia ideal untuk memperoleh keturunan guna mengurangi resiko/bahaya kematian bagi ibu dan bayi sehingga pada rentang usia ini mayoritas ibu akan banyak ditemukan memiliki anak infant dan toddler yang masih membutuhkan ASI (Potter \& Perry, 2010).

Berdasarkan tingkat pendidikan menunjukkan mayoritas responden berpendidikan vokasional yaitu jenis pendidikan tingkat Diploma III sebanyak $82.9 \%$ (29 orang). Pendidikan keperawatan di Indonesia mengacu kepada UU No. 20 
tahun 2003 tentang Sistem Pendidikan Nasional. Jenis pendidikan keperawatan di Indonesia mencakup pendidikan vokasional (pendidikan diploma III), pendidikan akademik (Strata I dan pasca sarjana), dan pendidikan profesi (Ners dan Spesialisasi) (INNA PPNI PUSAT, 2012). Hasil penelitian ini sesuai dengan keterangan Direktur Jenderal Bina Upaya Kesehatan Kementerian Kesehatan yang menyatakan sebagian besar $(80 \%)$ penerimaan pegawai profesi keperawatan yang bekerja di Rumah Sakit minimal Diploma III, namun saat ini sedang dalam proses menuju pendidikan strata (PPNIKotaBaru, 2011).

Ditinjau dari distribusi responden menurut status kepegawaian mayoritas berstatus Pegawai Negeri Sipil (PNS) sebanyak $51.4 \%$ (18 orang). PNS wanita memiliki masa cuti bersalin selama 3 bulan, 1 bulan sebelum melahirkan dan 2 bulan setelah melahirkan yang diatur dalam peraturan pemerintah nomor 24 tahun 1976 tanggal 23 Desember pasal 19 sampai dengan pasal 21 (Sarwadi, 2009). Sedangkan bagi tenaga honorer dan lainnya berdasarkan keterangan dari responden dan salah seorang kepala ruangan RSUD Arifin Achmad Pekanbaru diketahui masa cuti hamil hingga melahirkan yaitu 15 hari sebelum melahirkan dan 40 hari setelah melahirkan. Para ibu yang sedang dalam masa menyusui selama 6 bulan pertama tanpa mempertimbangkan status kepegawaiannya PNS, honorer ataupun lainnya diberikan kebijakan dari pihak Rumah Sakit dinas nonshift yaitu dinas hanya pada pagi saja dan kesempatan pulang lebih awal satu jam dari jadwal dinas biasanya guna menyusui bayi yang ditinggalkan dirumah.

Distribusi berdasarkan jumlah anak terbanyak yang dimiliki responden yaitu kelompok dengan jumlah anak 2-3 orang (62.9\% atau 22 responden). Jumlah anak yang dimiliki responden merupakan jumlah anak ideal yang masih ditanggung Negara (Sarwadi, 2009). Jumlah anak sebelumnya akan mempengaruhi pengetahuan ibu dalam tindakan mengasuh anak berikutnya.

Notoadmodjo (2003) menyatakan bahwa pengetahuan, sikap, dan tindakan seseorang dapat dipengaruhi oleh pengalaman masa lalu. Pengalaman adalah sesuatu yang pernah dialami (dijalani, dirasakan, dan ditanggung). Pengalaman pernah mengasuh anak dan memberikan ASI akan berdampak terhadap pandangan, sikap, dan tindakan ibu pada anak berikutnya.

Hasil penelitian ini menunjukkan sebagian besar ibu bekerja (perawat) yang punya anak lebih dari 1 (satu) orang tidak menjamin ibu belajar dari pengalaman sebelumnya untuk melakukan manajemen laktasi yang baik. Para ibu ini mayoritas masih berpandangan bahwa pemberian bantuan susu formula ketika ibu bekerja dianggap lebih tepat untuk memenuhi kebutuhan bayi dan menganggap bahwa hal ini dahulu juga dilakukan pada anak sebelumnya.

Berdasarkan umur anak terakhir yang dimiliki responden minoritas yaitu kelompok dengan umur >12-24 bulan (26\%), sedangkan mayoritas yaitu kelompok umur 7-12 bulan (40\%). Hal ini menunjukkan responden memiliki bayi dengan status telah melewati masa pemberian ASI eksklusif, namun masih dalam masa tetap memberikan ASI hingga usia 2 tahun atau 24 bulan sesuai rekomendasi dari WHO dan UNICEF, dan ibu ini seharusnya masih melakukan manajemen laktasi.

\section{Ruangan tempat responden bekerja}

Mayoritas responden bekerja di ruang perawatan kritis $(43 \%)$ dan tidak terlalu jauh berbeda jumlah responden yang bekerja di instalasi rawat inap (37\%), sedangkan minoritas bekerja di ruang poliklinik (3\%). Ibu bekerja (perawat) yang berasal dari berbagai ruangan yang berbeda tentunya memiliki karakteristik ruangan seperti pola kerja dan pola istirahat yang berbeda juga dengan ruangan lainnya. 
Pengalaman peneliti selama dinas di beberapa ruangan RSUD Arifin Achmad Pekanbaru, peneliti mengamati bahwa ruang perawatan kritis (perinatologi, PICU, ICU, CVCU) dan ruang emergency (OK Emergency \& UGD) memiliki pola kerja yang bersifat temporer dimana perawat bisa sangat sibuk hanya pada waktu-waktu tertentu saja atau dalam kondisi emergency seperti jika pasien sedang sangat kritis yang ditunjukkan melalui monitor, sedangkan di instalasi rawat inap sebagian besar memiliki pola kerja yang intermiten dimana kesibukan dapat berlangsung setiap saat, namun hanya sebentar. Perawat yang bekerja baik di ruang perawatan kritis, emergency ataupun instalasi rawat inap sebenarnya masih bisa istirahat dan memanfaatkan waktu tersebut untuk memerah dan menyimpan ASI, berbeda dengan poliklinik yang sibuk setiap saat namun didukung dengan jam kerja yang lebih singkat dari ruang lainnya yaitu sekitar $4-6$ jam, nonshift yaitu jam kerja hanya pada pagi hari, dan di hari jum'atsabtu jam dinas lebih pendek lagi, sedangkan di hari minggu dan tanggal merah libur sehingga peluang pemberian ASI eksklusif 6 bulan pada bayi seharusnya dapat dilakukan secara optimal.

\section{Lama pemberian ASI Eksklusif}

Rata-rata lama pemberian ASI eksklusif yang dilakukan perawat adalah 2.49 bulan. Lama pemberian ASI eksklusif paling rendah 0 bulan (tidak memberikan ASI eksklusif) dan paling lama yaitu 6 bulan. ASI eksklusif adalah pemberian ASI saja kepada bayi tanpa tambahan cairan atau makanan lainnya (LINKAGES, 2001). The American of Pediatrics (AAP) merekomendasikan bahwa bayi selama 6 bulan pertama kehidupannya diberikan ASI eksklusif dan ditambah dengan pemberian MP-ASI (Makanan Pendamping-ASI) tepat setelah bayi berusia 6 bulan dan pemberian ASI tetap dilanjutkan hingga anak berusia 2 tahun.
Bekerja dan tetap memberikan ASI untuk bayi memiliki tantangan karena menyusui memerlukan proses adaptasi antara ibu termasuk ibu berprofesi perawat dengan bayi. Setelah bekerja, ibu (perawat) harus berjuang keras untuk menyusui dirumah, memerah dan tetap bekerja dengan baik di tempat kerja (Swandari, 2012).

Pemberian ASI eksklusif yang ratarata 2.49 atau 3 bulan dikalangan perawat ini mengindikasikan rata-rata ibu (perawat) hanya mampu mempertahankan pemberian ASI selama ibu dalam masa cuti 3 bulan terutama bagi PNS, sedangkan faktor lainnya yang menyebabkan lama pemberian ASI yang belum optimal ini kemungkinan disebabkan oleh faktor internal ibu (perawat) seperti pemahaman tentang ASI eksklusif, dan faktor dari lingkungan sosial perawat bekerja seperti minimnya informasi tentang ASI dibeberapa ruangan kecuali di ruangan perinatologi dan ruang perawatan anak, pengalaman rekan sesama perawat yang lebih banyak memilih susu formula ketika ibu bekerja, dan belum ada ruangan khusus laktasi di setiap ruangan perawat bekerja (Wulandari et al., 2009).

\section{Manajemen laktasi}

Dari hasil analisa diketahui bahwa manajemen laktasi yang dilakukan ibu (perawat) masih belum terlalu baik/optimal. Ibu menyusui yang berprofesi sebagai perawat mungkin telah mengetahui tentang manajemen laktasi selama masa pendidikan dahulunya, namun pengetahuan yang didapatkan belum dipahami, diaplikasikan, disintesis, dan dievaluasi setelah menjadi ibu secara optimal. Sekedar tahu dengan pengetahuan yang didapatkan, namun belum diwujudkan melalui tindakan, akan membuat manajemen laktasi menjadi kurang optimal, dan pengetahuan yang kurang tentang manajemen laktasi tidak membuat tindakan akan menjadi kurang baik. 
Hasil penelitian Harjanti (2010) menyatakan perilaku manajemen laktasi yang baik pada ibu bekerja sebagai perawat menunjukkan hanya pada ruang lingkup pemenuhan asupan gizi yang baik selama periode menyusui dan teknik menyusui. Sedangkan berada pada kategori buruk untuk pemberian ASI eksklusif, teknik memerah ASI, teknik menyimpan ASI, dan teknik memberikan ASI perah.

Hasil penelitian Wenas, Malonda, Bolang, \& Kapantow (2012), tidak ada hubungan antara pengetahuan ibu dengan pemberian ASI eksklusif, namun ada hubungan sikap ibu dengan pemberian ASI eksklusif yang ditunjukkan sama dengan penelitian Wulandari et al. (2009) yang menyatakan bahwa terdapat hubungan sikap dengan pemberian ASI eksklusif, namun bertolak belakang bahwa terdapat hubungan pengetahuan juga terhadap pemberian ASI eksklusif.

Faktor lain yang mungkin menyebabkan skor manajemen laktasi pada ibu bekerja (perawat) belum optimal yaitu isi kuesioner yang belum mendalam menanyakan tentang perilaku ibu (perawat) tentang waktu dan ruangan ibu biasanya menyusui/memompa ASI selama jam kerja, serta cara ibu memberikan ASI (menggunakan sendok/cangkir/dot).

\section{Dukungan keluarga}

Hasil penelitian menunjukkan ratarata skor dukungan keluarga terhadap ibu bekerja (perawat) adalah 15.26 yang berada pada rentang skor pertengahan $(95 \% \mathrm{CI}=$ 13.73-16.78) dengan rentang skor total dari 22 pertanyaan yaitu 0 - 22. Dari hasil analisa diketahui bahwa dukungan keluarga yang didapatkan oleh ibu bekerja (perawat) tidak tinggi dan tidak rendah.

Friedman et al. (2003) menyatakan bahwa keluarga memiliki beberapa fungsi/jenis dukungan yaitu dukungan informasional dalam bentuk keluarga sebagai penyebar informasi, dukungan penilaian dimana keluarga bertindak membimbing dan menengahi permasalahan, dukungan instrumental yaitu keluarga sebagai sebuah sumber pertolongan praktis dan konkrit, dan dukungan emosional yaitu keluarga sebagai tempat yang aman dan damai untuk istirahat dan pemulihan.

Dukungan keluarga berkaitan dengan pembentukan keseimbangan mental dan kepuasan psikologis. Anggota keluarga memandang bahwa orang bersifat mendukung selalu siap memberikan pertolongan dan bantuan jika diperlukan (Manaf, 2010). Dukungan dari anggota keluarga akan membantu dalam keberhasilan suatu tindakan (Wong, et al., 2006). Pemberian dukungan dari suami dan keluarga dapat meningkatkan kepercayaan diri, kenyamanan, dan pengalaman keberhasilan ibu dalam menyusui (Lowdermilk \& Perry, 2004; Basavanthappa, 2006).

Tantangan bagi ibu bekerja yang memiliki peran ganda yaitu sebagai seorang ibu dan istri di rumah dan sebagai wanita karir dituntut agar peran ini dapat berjalan secara seimbang sehingga ibu bekerja termasuk perawat disamping membutuhkan dukungan dari keluarga di rumah juga perlu adanya dukungan dari tempat bekerja agar berhasil dalam tindakan manajemen laktasi.

Hasil penelitian Novayelinda (2009) menyatakan bahwa dukungan tempat kerja yang paling banyak didapatkan ibu adalah tersedianya lemari pendingin untuk menyimpan ASI dan dukungan kebijakan dengan memperbolehkan wanita bekerja mendapatkan istirahat khusus untuk menyusui atau memerah ASI. Sedangkan jenis fasilitas yang paling sedikit diberikan adalah penyediaan pompa ASI oleh tempat kerja dan pemberian informasi tentang manajemen laktasi. Penelitian ini hampir sama dengan hasil penelitian yang didapatkan dan berdasarkan pengalaman peneliti dinas di RSUD Arifin Achmad Pekanbaru dimana hampir dari seluruh ruangan kecuali poliklinik dimana responden bekerja tersedia lemari 
pendingin dan ruang khusus ganti pakaian dan istirahat yang dapat dimanfaatkan oleh perawat menyusui untuk memompa dan menyimpan ASI Perah.

Sedangkan jenis fasilitas penyediaan pompa ASI dan pemberian informasi tentang manajemen laktasi hanya ada diruang perinatologi dan ruang rawat inap khusus anak. Ruangan lainnya sangat minim informasi tentang manajemen laktasi dan tidak ada fasilitas penyediaan pompa ASI. Disamping fasilitas yang disediakan dari tempat kerja tidak terlepas juga ada peran dan pengaruh dari dukungan rekan sesama perawat. Pengalaman rekan sesama perawat yang pernah menyusui dan bekerja akan diperkirakan menjadi salah satu faktor pendukung ibu (perawat) dalam melakukan manajemen laktasi.

\section{B. Hubungan dukungan keluarga terhadap manajemen laktasi pada ibu bekerja}

Hasil analisa dengan menggunakan uji korelasi Pearson antara variabel skor manajemen laktasi dan skor dukungan keluarga pada ibu bekerja menunjukkan korelasi sebesar 0.295. Angka tersebut bermakna adanya korelasi positif yang lemah $(0.20-0.399)$ dan searah. Artinya, semakin besar variabel skor dukungan keluarga maka variabel skor manajemen laktasi pada ibu bekerja juga semakin besar. Dari hasil analisa tersebut diperoleh juga $\mathrm{P}$ value sebesar 0.086 ( $\mathrm{P}$ value $>0,05)$ yang menunjukkan bahwa antara keduanya tidak terdapat korelasi yang bermakna, ini berarti $\mathrm{H}_{0}$ gagal ditolak, sehingga tidak ada hubungan antara dukungan keluarga terhadap manajemen laktasi pada ibu bekerja.

Hasil ini sesuai dengan hasil penelitian Emiliani (2012) yang menyatakan bahwa tidak ada hubungan antara dukungan keluarga dengan pemberian ASI eksklusif. Demikian juga dengan hasil penelitian Quintao (2003) yang menyatakan bahwa tidak ada hubungan dukungan suami dengan praktek pemberian ASI eksklusif. Berdasarkan penelitian yang dilakukan oleh Goe (2011) juga menunjukkan hasil yang hampir serupa dimana sebagian besar keluarga mendukung ibu memberikan ASI eksklusif pada bayi, namun sebagian besar ibu menyusui tidak eksklusif sehingga didapatkan hasil bahwa tidak ada hubungan dukungan keluarga terhadap pemberian ASI eksklusif. Demikian juga dengan hasil penelitian yang dilakukan di Taiwan pada sebuah perusahaan produsen semikonduktor yang peduli dan mendukung ibu untuk terus menyusui walaupun telah kembali bekerja dengan menyediakan ruang khusus laktasi dan alat pemompa ASI, serta waktu istirahat untuk memerah ASI selama bekerja, namun hanya $10,6 \%$ ibu yang peduli akan kebijakan ini dan tetap terus memberikan ASI pada bayinya setelah kembali bekerja (Chen, Wu, \& Chie, 2006).

Bertentangan dengan hasil penelitian Manaf (2010) dan Simbolon (2011) yang menyatakan ada hubungan antara dukungan keluarga dengan pemberian ASI eksklusif pada ibu bekerja. Demikian juga dengan hasil penelitian Rejeki (2008) yang menyatakan ada hubungan antara dukungan keluarga pada ibu bekerja terhadap keberhasilan ibu mempertahankan pemberian ASI.

Kesenjangan ini terjadi kemungkinan dipengaruhi dari karakteristik responden yang berbeda, responden pada penelitian ini yaitu ibu bekerja yang berprofesi sebagai perawat, sedangkan peneliti sebelumnya menggunakan responden yang berasal dari berbagai profesi pekerjaan. Sehingga hasil penelitian ini didapatkan antara dukungan keluarga dengan manajemen laktasi sama-sama berada pada skor pertengahan yang menyebabkan tidak ada hubungan antara kedua variabel tersebut.

Blais, Hayes, Kozier, \& Erb (2007) mengungkapkan bahwa perawat memiliki peran dalam promosi kesehatan yaitu menjadi panutan perilaku dan sikap gaya 
hidup sehat, mengajarkan orang lain mengenai strategi perawatan diri untuk meningkatkan kebugaran, memperbaiki nutrisi, mengatasi stres, dan meningkatkan hubungan. Sehingga keluarga terutama suami, ibu kandung, atau mertua perempuan kemungkinan tidak terlalu banyak memberikan dukungan terkait ASI dan manajemen laktasi pada ibu dikarenakan ibu yang berprofesi sebagai perawat tentunya telah memiliki bekal pengetahuan mengenai manajemen laktasi.

Roesli (2000) berpendapat bahwa seringkali ibu yang bekerja termasuk perawat mengalami dilema dalam memberikan ASI eksklusif pada bayinya meskipun kelompok ini tahu manfaat dan keunggulan ASI, namun sulit untuk mempraktekkannya. Sekedar tahu namun belum memahami, mengaplikasikan, mensistesis, dan mengevaluasi apa yang diketahui membuat sikap dan tindakan ibu (perawat) dalam manajemen laktasi belum optimal. Sebenarnya sikap dan tindakan ibu yang berprofesi perawat terkait manajemen laktasi yang belum optimal tidak bisa dilihat dari satu aspek saja, walaupun tidak ada hubungan antara dukungan keluarga dengan manajemen laktasi pada ibu bekerja (perawat) namun kemungkinan ada pengaruh faktor lainnya seperti perilaku rekan sesama perawat yang sebelumnya tidak memberikan ASI secara eksklusif, kondisi pekerjaan seperti pola kerja dan pola istirahat yang tidak mendukung untuk melakukan pemompaan ASI saat bekerja, kondisi fisik/kesehatan ibu yang rentan mengalami sakit karena terpapar lama dengan lingkungan rumah sakit, cuti melahirkan yang terlalu singkat, serta gencarnya promosi dan penjualan susu formula.

Produk susu formula yang saat ini banyak beredar dipasaran, mudah dibeli masyarakat, dan dianggap praktis membuat ibu bekerja termasuk perawat lebih memilih susu formula dan mengabaikan aspek nutrisi, pembangun sumber daya manusia yang berkualitas, serta aspek psikologis bagi ibu, keluarga, dan bayi yang jauh lebih baik diberikan melalui pemberian ASI (Newman \& Pitman, 2008; Jenny, 2006). Pada dasarnya manajemen laktasi tergantung atas keputusan ibu sendiri. Ibu bekerja (perawat) tidak akan berhasil melakukan manajemen laktasi yang optimal tanpa disertai keyakinan dan tekad yang kuat, disamping keluarga dan lingkungan sosial kerja juga memberikan dukungan.

\section{KESIMPULAN DAN SARAN}

Setelah dilakukan penelitian tentang hubungan dukungan keluarga terhadap manajemen laktasi pada ibu bekerja (perawat) di RSUD Arifin Achmad Pekanbaru pada 35 orang perawat, diketahui bahwa mayoritas responden berada pada rentang umur 21-35 tahun $(94,3 \%)$, memiliki tingkat pendidikan paling banyak yaitu Diploma (82,9\%), berstatus pegawai PNS $(51,4 \%)$, jumlah anak yang dimiliki 2-3 orang (63\%), umur anak terakhir yang dimiliki umur 7-12 bulan (40\%), dan rata-rata durasi pemberian ASI eksklusif yaitu selama 2,49. Berdasarkan hasil analisa bivariat dengan menggunakan uji korelasi Pearson menunjukkan tidak terdapat hubungan dukungan keluarga terhadap manajemen laktasi pada ibu bekerja.

Disarankan bagi rekan kerja perawat agar dapat memotivasi, meyakinkan, dan mendukung ibu untuk melakukan manajemen laktasi sehingga diharapkan dapat ditularkan kepada masyarakat. Bagi pihak rumah sakit dan pembuat kebijakan dapat memberikan informasi terkait manajemen laktasi melalui poster, buku, ataupun seminar terutama ditujukan bagi perawat yang dalam rentang usia produktif yang kemungkinan besar akan mengalami masa hamil, melahirkan, dan menyusui.
1. Arlia Purwaningsih, S.Kep. Mahasiswa Program Studi Ilmu Keperawatan Universitas Riau 
2. Oswati Hasanah, M.Kep., Sp.Kep.An.

Dosen Departemen Keperawatan Anak Program Studi Ilmu Keperawatan Universitas Riau

3. Wasisto Utomo, M.Kep.,Sp.KMB. Dosen Departemen Keperawatan Medikal Bedah Program Studi Ilmu Keperawatan Universitas Riau

\section{DAFTAR PUSTAKA}

Agoestingoe, E. R. (2011). Tingkat pengetahuan ibu bekerja tentang manajemen laktasi ibu bekerja berdasarkan karakteristik individu di kelurahan tugurejo Kecamatan tugu kota semarang. Semarang: Universitas Muhammadiyah Semarang. Skripsi. Diperoleh tanggal 21 Januari 2013 dari http://digilib.unimus.ac.id/files/disk 1/118/jtptunimus-gdl-ellsaryant5872-1-babi.pdf

Basavanthappa, B. T. (2006). Midwifery and reproductive health nursing. New Delhi: Jaypee Brothers Medical Publishers (P) Ltd.

Blais, K. K., Hayes, J. S., Kozier, B., Erb, G. (2002). Praktik keperawatan professional: Konsep \& Perspektif. Jakarta: EGC.

Chen, Y. C., Wu, Y. C., \& Chie, W. C. (2006). Effects of work-related factors on the breastfeeding behavior of working mothers in a Taiwanese semiconductor manufacturer: A cross-sectional survey. BMC Public Health, 160 (6) (online OVID/ Medline). Diperoleh tanggal 20 Juni 2013 dalam http://ncbi.nlm.nih.gov/pmc/articles /PMC1538587/

Datta, P. (2009). Pediatric nursing $2^{\text {nd }}$ edition. New Delhi: Jaypee
Brothers Medical Publishers (P) Ltd.

Depkes RI. (2007). Pedoman penyelenggaraan pelatihan konseling menyusui dan pelatihan fasilitator konseling menyusui. Jakarta: Departemen Kesehatan 2007.

Dinas Kota Pekanbaru. (2012). Cakupan pemberian ASI Eksklusif di Kota Pekanbaru.

Emiliani. (2012). Faktor-faktor yang berhubungan dengan pemberian ASI eksklusif. Pekanbaru: Program Studi Ilmu Keperawatan Universitas Riau. Tidak dipublikasikan. Skripsi.

Friedman, M. M., Bowden, V. R., \& Jones, E. G. (2003). Family nursing: Research, theory, \& practice. Edisi ke-5. New Jersey: Pearson Education.

Goe, N. Y. (2011). Hubungan dukungan keluarga terhadap pemberian Air Susu Ibu (ASI) eksklusif pada bayi usia 7-12 bulan di wilayah kerja puskesmas kedungmundu kota semarang tahun 2011. Diperoleh tanggal 06 Juni 2013 dalam http://digilib.unimus.ac.id/gdl.php? $\bmod =$ browse $\& o p=$ read $\&$ id=jtptuni mus-gdl-nitayulian-5844 Universitas Muhammadiyah Semarang. Skripsi.

Harjanti, N. (2010). Perilaku Perawat Dalam Manajemen Laktasi di RSUD Tugorejo Semarang. Diperoleh tanggal 12 oktober 2012 dari http://eprints.undip.ac.id/10723/1/ar tikel.pdf

INNA PPNI PUSAT. (2012). Pendidikan keperawatan di Indonesia. 
Diperoleh tanggal 20 Juni 2013 dalam http://innappni.or.id/index.php/keperawatandi-indonesia/pendidikankeperawatan

InfoPublik Direktorat Jenderal Informasi dan Komunikasi Publik Kementerian Komunikasi dan Informatika. (2010). Pemberian ASI Eksklusif di Indonesia Masih Rendah diperoleh tanggal 06 Februari 2013 dari http://infopublik.kominfo.go.id/inde xb11f.html?page $=$ news\&newsid $=51$ 7

Jenny, S. (2006). Perawatan masa nifas ibu dan bayi. Yogyakarta: Sahabat setia.

Kementerian Kesehatan RI Direktorat Jenderal Bina Gizi dan Kesehatan Ibu dan Anak. (2012). Kinerja kegiatan pembinaan gizi tahun 2011 menuju perbaikan gizi perseorangan dan masyarakat yang bermutu diperoleh pada tanggal 11 Nopember 2012 pukul 15.33 WIB dalam http://www.gizi.depkes.go.id/wpcontent/uploads/2012/08/BukuLaptah-2011.pdf

Kementerian Kesehatan. (2012). di peroleh tanggal 12 oktober 2012 pukul 20.10 wib dari http://depkes.go.id/index.php/berita/ press-release/1662-ibu-bekerjabukan-alasan-menghentikanpemberian-asi-eksklusif.html

LINKAGES. (2001). Developmental readiness of normal full term infants to progress from exclusive breastfeeding to the introduction of complementary foods: Reviews of the relevant literature concerning infant immunologic, gastrointestinal, oral motor and maternal reproductive and lactational development. Diperoleh tanggal 01 Nopember 2012 dari www.linkagesproject.org

Lowdermilk., \& Perry. (2004). Maternity and women's health care. $\left(8^{\text {th }} \mathrm{ed}\right.$. Vol. 2). St. Louis: Mosby.

Manaf, S. A. (2010). Pengaruh dukungan keluarga terhadap pemberian ASI eksklusif pada ibu bekerja di Kecamatan Darul Imarah Kabupaten Aceh Besar Tahun 2009. Medan: Program Studi S2 Ilmu Kesehatan Masyarakat Fakultas Kesehatan Masyarakat Universitas Sumatera Utara. Tesis. Diperoleh tanggal 22 Nopember 2012 dari http://repository.usu.ac.id/handle/12 3456789/31289\&sa=U\&ei=NuQBu bTuOOqoiQLInoHQDQ\&ved $=\mathrm{oCB}$ $\mathrm{UQFj}$

Newman, J \& Pitman, T. (2008). The ultimate breastfeeding book of answers: Segala yang perlu anda tahu soal menyusui. TorontoCanada: HarperCollins Publishers Ltd.

Notoatmodjo, S. (2003). Ilmu kesehatan masyarakat prinsip-prinsip dasar. Jakarta: Rineka Cipta.

Novayelinda, R. (2009). Gambaran dukungan yang diberikan tempat bekerja dalam pemberian ASI. Prosiding seminar nasional keperawatan Universitas Riau: Peningkatan kualitas penelitian keperawatan melalui "Multicentre Research". Persatuan Perawat Nasional Indonesia Provinsi Riau 21-22 Oktober 2011.

PPNI Kabupaten Kotabaru. Perawat mendominasi tenaga kesehatan. Diperoleh tanggal 19 Juni 2013 
dalam

http://ppnikotabaru.wordpress.com/ page/2/

Potter, P. A \& Perry, A. G. (2010). Fundamental keperawatan. Edisi 7. Buku 1. Jakarta: EGC.

Quintao, A. D. A. (2003). Beberapa faktor yang berhubungan dengan praktek pemberian ASI eksklusif di Desa Kalisid, Kecamatan Ungaran Kabupaten Semarang Tahun 2003. Thesis. Universitas Diponegoro. Diperoleh tanggal 06 juni 2013 dalam http://eprints.undip.ac.id/7115/

Rejeki, S. (2008). Pengalaman Menyusui Eksklusif Ibu Bekerja di Wilayah Kendal Jawa Tengah. Media Ners, $1(2), 1-44$.

Riset Kesehatan Dasar (Riskesdas, 2010). Riset kesehatan dasar 2010. Diperoleh tanggal 07 Oktober 2012 dari http://www.riskesdas.litbang.depkes .go.id/2010/

Roesli, U. (2000). Mengenal ASI eksklusif. Jakarta: Trubus Agriwidya.

Sarwadi. (2009). Tinjauan atas hak cuti pegawai negeri sipil dalam peraturan pemerintah nomor 24 tahun 1976 dan surat edaran sekretaris jenderal kementerian keuangan nomor SE 3559/MK.1/2009/Tanggal 10 Desember 2009. Diperoleh tanggal O6 Juni 2013 dalam www.bppk.depkeu.go.id/webpegaw ai/attachments/414_TinjauanCutiP NS_Sarwadi.pdf

Simbolon, P. (2011). Pengaruh dukungan keluarga terhadap pemberian ASI Eksklusif di wilayah kerja puskesmas Gurilla

Pematangsiantar. Medan: Program

Studi S2 Ilmu Kesehatan

Masyarakat Fakultas Kesehatan

Masyarakat Universitas Sumatera

Utara. Tesis. Diperoleh tanggal 15 Januari 2013 dari http://repository.usu.ac.id/bitstream/ 123456789/31289/7/cover.pdf

Swandari, S. (2013). Manajemen laktasi bagi ibu bekerja. Diperoleh tanggal 20 Januari 2013 dari http://bbpkmakassar.or.id/index.php /Umum/Info-

Kesehatan/Manajemen-Laktasibagi-Ibu-Bekerja.phd

Syafiq, A., \& Fikawati, S. (2010). Kajian implementasi dan kebijakan air susu ibu eksklusif dan inisiasi menyusu dini di Indonesia. Makara kesehatan, 1(14), 17-24. Diperoleh tanggal 10 Oktober 2012 dari http://journal.ui.ac.id/index.php/hel ath/article/download/642/627.

Wenas, W., Malonda, N. S. H., Bolang, A. S. L., \& Kapantow, N. H. (2012). Hubungan antara pengetahuan dan sikap ibu menyusui dengan pemberian air susu ibu eksklusif di wilayah kerja puskesmas tompaso kecamatan tompaso. Bidang minat gizi, fakultas kesehatan masyarakat universitas Sam Ratulangi Manado. Diperoleh tanggal 30 mei 2013 dari http://fkm.unsrat.ac.id/wpcontent/uploads/2012/10/WinlyWenas.pdf)

Wulandari, S., Komariah, M., \& Ermiati. (2009). Hubungan pengetahuan dan sikap dengan pemberian ASI eksklusif oleh ibu-ibu yang bekerja sebagai perawat di RS Al.Islam Kota Bandung. Volume 10 No. XIX Oktober 2008-Februari 2009 Hal 85. Diperoleh tanggal 28 Oktober 
2012 dari http://jurnal.unpad.ac.id/ $\mathrm{mku} /$ article/view/55

Wong, D. L., Hockenberry, M. J., Wilson,
D.,
Perry.
Lowdermilk.

(2006). Maternal child nursing care $3^{\text {rd }}$ edition. St. Louis: Mosby Elsevier. 